DOI: 10.34015/2523-4552.2020.1.11

УДК 343.985: 340.69: 343.148

Симоненко Н. О.,

кандидат юридичних наук,

доцент кафедри кримінального права

Національної академії внутрішніх справ

e-mail: Natalka_88@ukr.net

ORCID: 0000-0003-1048-278X

\title{
ОСОБЛИВОСТІ ПРОВЕДЕННЯ ОКРЕМИХ СУДОВИХ ЕКСПЕРТИЗ ПІД ЧАС РОЗСЛІДУВАННЯ ЗЛОЧИНІВ МИНУЛИХ РОКІВ
}

Стаття присвячена дослідженню проведення судово-медичної і психофізіологічної експертизи в ході досудового розслідування злочинів минулих років. Особливу увагу автор приділяє питанням, пов'язаним з проведенням судово-медичної, судово-психіатричної та судово-психологічної експертизи, а також проведенню психофізіологічної експертизи з використанням полігра$\phi$ a.

Ключові слова: експерт; злочини минулих років; розслідування; судова експертиза; психофізіологічна експертиза з використанням поліграфа.

Статья посвящена исследованию проведения судебно-медицинской и психофизиологической экспертизы в ходе досудебного расследования преступлений прошлых лет. Особое внимание автор уделяет вопросам, связанным с проведением судебно-медицинской, судебно-психиатрической и судебно-психологической экспертизы, а также проведению психофизиологической экспертизы с использованием полиграфа.

Ключевые слова: эксперт; преступления прошлых лет; расследование; судебная экспертиза, психофизиологическая экспертиза с использованием полиграфа.

Постановка проблеми. Доволі часто в практиці під час досудового розслідування злочинів минулих років та наступного розгляду кримінальних проваджень у суді виникає потреба у вирішенні питань, на які один фахівець не може надати відповіді, оскільки не володіє сповна всіма необхідними спеціальними знаннями. У такому випадку виникає потреба в проведенні судових експертиз. Адже важливим засобом встановлення нових фактичних даних і пе- ревірки зібраних доказів під час досудового розслідування минулих років $\epsilon$ судова експертиза. Висновок експерта $є$ одним із найважливіших доказів під час досудового розслідування злочинів. Підстави проведення та порядок призначення експертиз щодо кримінального провадження передбачені КПК України, Законом України «Про судову експертизу» та Інструкцією про призначення та проведення судових експертиз та експертних досліджень, затвердже- 
ною наказом Міністерства юстиції України.

Аналіз останніх досліджень і публікацій. Проблеми призначення та проведення судово-медичних експертиз досліджували такі вчені: Т. В. Авер'янова, Р. С. Бєлкін, Г. Гросс, Н. І. Клименко, В. В. Коваленко, $\begin{array}{ll}\text { М. В. Костицький, } & \text { В.П. Колмаков, }\end{array}$ Г. Я. Лемик, $\quad \in$. Д. Лук'янчиков, В. Я. Марчак, В. М. Махов, А. А. Меденцев, Т.Ф. Моїсеєва, І. В. Озерський, В.В. Семенов, $\quad$ В. Ю. Шепітько, В. М. Шерстюк, А. В. Ярош та ін. Водночас, незважаючи на значну кількість праць, які присвячені призначенню та проведення судовомедичних експертиз, у працівників правоохоронних органів виникають численні труднощі, пов'язані з недосконалістю кримінального процесуального законодавства.

Постановка завдання. Метою статті $є$ окреслення проблемних питань, пов'язаних із проведенням окремих судових експертиз при розслідування злочинів минулих років, та викладення власної думки щодо окремих шляхів їх вирішення.

Виклад основного матеріалу. Визначення поняття «судова експертиза» міститься у Законі України «Про судову експертизу», що формулює судову експертизу як дослідження на основі спеціальних знань у галузі науки, техніки, мистецтва, ремесла тощо об'єктів, явищ і процесів 3 метою надання висновку 3 питань, які $\epsilon$ або будуть предметом судового розгляду (ст. 1 Закону України «Про судову експертизу»).

Експертиза проводиться експертом за зверненням сторони кримінального провадження або за дорученням слідчого судді чи суду, якщо для з'ясування обставин, що ма- ють значення для кримінального провадження, необхідні спеціальні знання (ч. 1 ст. 242 КПК України). Підстави проведення судовомедичних експертиз під час досудового розслідування злочинів минулих років визначені кримінальним процесуальним законодавством, якщо для з'ясування обставин, що мають значення для кримінального провадження, потрібні наукові, технічні та інші спеціальні знання. А. А. Меденцов виділяє такі підстави для призначення судово-медичної експертизи під час досудового розслідування злочинів: 1) під час експертизи тілесних ушкоджень для встановлення їх наявності, особливостей і ступеня тяжкості; визначення ступеня втрати загальної і професійної працездатності; оцінки стану здоров'я, симуляції, дисимуляції, агравації, вигаданих хвороб і калічення членів; виявлення рубців як наслідків ушкоджень чи хвороб; 2) під час експертизи стосовно спірних статевих станів для встановлення статі; порушення цілісності дівочої пліви; для визначення статевої репродуктивної функції, а також вагітності й пологів, які відбулися; 3) під час проведення експертизи при статевих злочинах для встановлення факту насильницького статевого акту, характеру i механізму виникнення ушкоджень під час його скоєння; визначення насильницького статевого акту в спотвореній формі; виявлення розбещувальних дій щодо неповнолітніх, а також статевих зносин з особами, які не досягли шістнадцятирічного віку; зараження венеричною хворобою, СНІД, ВІЛ-інфекцією; 4) експертиза з інших приводів проводиться для встановлення віку; тотожності особи; у випадках спірного 
батьківства і підміни дітей, а також для встановлення факту і ступеня алкогольного сп'яніння [4].

$€$ певна категорія злочинів, для якої у кримінальному процесуальному кодексі зазначається, що проведення судово-медичної експертизи $\epsilon$ обов'язковим, наприклад, під час досудового розслідування злочинів проти здоров'я особи. Однак, якщо це стосується злочинів минулих років, то ії̈ проведення буде мати особливе значення для досудового розслідування даного виду злочинів, адже після його вчинення минув певний проміжок часу. Це питання є досить дискусійним серед науковців, які вивчали нерозкриті злочини минулих років. Так, В. Я. Горбачевський, B. I. Захаров, I. O. Іерусалимов зазначили, що протягом тривалого часу втрачаються ідентифікаційні ознаки в невиявлених своєчасно предметах. Зокрема, може зношуватися взуття, тупитися або, навпаки, заточуватися сокири, ножі та інші гострі знаряддя злочину, зазнають змін протектори покришок автомашин і мотоциклів, деталі вогнепальної зброї тощо. Усе це може ускладнити ідентифікацію цих об'єктів за залишеними слідами, а іноді робить ототожнення взагалі неможливим. Крім того, змінюються зовнішні ознаки особи, яка вчинила злочин, що деякою мірою ускладнює iï ідентифікацію за фотознімками [6, c. 58].

Але М. О. Яковенко, який має іншу думку, визначив низку позитивних чинників проведення даної слідчої (розшукової) дії щодо відновленого кримінального провадження, одним із яких $є$ науковий прогрес, що надає нові можливості як при ідентифікації об'єктів, так і при вирішенні діагностичних завдань. Незнання злочинцями нових досягнень науки і техніки, взятих на озброєння правоохоронними органами, може сприяти розкриттю злочину (наприклад, залишені на місці події недопалки, рукавички та інші предмети, що можуть зберегти на собі біологічні залишки організму особи злочинця). У результаті цього при проведенні експертизи дослідження ДНК (дослідження молекули дезоксирибонуклеїнової кислоти) з'являється можливість ідентифікувати на мікроскопічному рівні такі об'єкти, як залишки слини, поту, волосся, епідермісу, й досягти високого рівня вірогідності висновків. Таким чином, це дає змогу не лише встановити особу злочинця шляхом порівняльної ідентифікації зразків, відібраних на початковому етапі розслідування, а й отримати надійні докази, що мають стати ключовими в процесі розгляду провадження судом раніше [7, с. 78].

У разі, якщо під час досудового розслідування даного злочину вже було проведено первинну експертизу, але вона не дала достатніх результатів або була виконана 3 певними порушеннями, слідчий суддя може дати дозвіл на проведення додаткової або повторної експертизи. У такому разі до експертної установи надаються також висновки попередніх експертиз з усіма додатками, а також додаткові матеріали, що стосуються предмета експертизи, які були зібрані після надання первинного висновку.

У висновку експерта при проведенні повторної експертизи вказуються причини розбіжностей 3 висновками попередніх експертиз, якщо такі розбіжності мали місце. Отже, щодо проведення судовомедичної експертизи під час досудо- 
вого розслідування злочинів минулих років слідчому насамперед слід ретельно вивчити матеріали кримінального провадження та висновки експерта щодо проведення попередніх експертиз і вирішити, які судовомедичні експертизи слід проводити цього разу:

- первинну, якщо дана експертиза не проводилася за даним провадженням;

- повторну, якщо дана експертиза проводилася, але у слідчого виникли сумніви щодо об'єктивності висновків експертиз;

- додаткову, при появі нових суттєвих питань, які можуть допомогти слідчому під час досудового розслідування даного злочину;

- комплексну, за необхідності під час проведення судово-медичної експертизи задіяти спеціалістів різних галузей знань.

Кримінальне процесуальне законодавство зобов'язує проведення судово-психіатричної експертизи для визначення психічного стану підозрюваного за наявності відомостей, які викликають сумнів щодо його осудності та обмеженої осудності (п. 3 ч. 2 ст. 242 КПК України).

Так, на думку В. Г. Гончаренка, підставами для проведення даної експертизи є: обумовленість важливістю обставин, які відомі або можуть бути відомі особі і які підлягають доказуванню у кримінальному провадженні, без чого встановлення істини є ускладненим; наявність достатніх фактичних підстав, що свідчать про певні неадекватні особливості поведінки особи, які можуть вказувати на наявність у неї психічних розладів (неадекватна поведінка в побуті, немотивована збудженість, непослідовність і суперечливість пояснень під час кримінального провадження, нерозуміння загальноприйнятих і суспільно визначених категорій, надмірно низький рівень загальноосвітніх знань тощо); наявність інформації про перенесення особою захворювань і травм, що супроводжувалися зміною поведінки, інформація про перебування особи на психіатричному обліку тощо [8].

Особливість проведення судово-психіатричної експертизи залежить від специфіки поставлених питань перед експертом. Якщо судовопсихіатрична експертиза призначається для встановлення осудності підозрюваного, тоді слід визначити, чи є відомості про психічні захворювання і про психічні розлади, що спостерігалися після травми черепа, інфекційних хвороб, отруєнь та інших соматичних страждань, то відповідна медична документація має бути витребувана 3 лікувальних установ, у яких лікувався підозрюваний унаслідок цих захворювань. Якщо ж у підозрюваного виявляються неадекватності в поведінці, але він заперечує, що лікувався в психіатра, необхідно уточнити цю обставину в психоневрологічному диспансері за місцем проживання. Коли у слідчого виникає сумнів про психічне здоров'я підозрюваного, то до направлення його на експертизу необхідно допитати свідків про поводження цієї особи. Важливо допитати свідків про поводження і вислови підозрюваного безпосередньо перед вчиненням злочину, у період його вчинення і безпосередньо після вчинення [9].

Головні питання, які слідчий ставить експерту в дорученні на проведення судово-психіатричної експертизи злочинів минулих років: 
1. Чи не хворів підозрюваний на психічне захворювання в момент вчинення злочину? Якщо хворів, то на яке захворювання?

2. Якщо підозрюваний хворів на психічне захворювання у момент злочину, то чи усвідомлював він свої дії і міг керувати ними?

3. Чи не хворіє підозрюваний на психічне захворювання, що виникло після вчиненого ним злочину? Якщо так, то чи може він усвідомлювати свої дії та керувати ними?

4. Чи потребує підозрюваний застосування до нього заходів медичного характеру? Якщо так, то яких саме?

5. Чи не хворіє потерпіла особа на психічне захворювання? Якщо так, то на яке захворювання?

6. Чи психічне захворювання в потерпілої особи виникло під час вчиненого злочину чи вона вже була хвора в момент вчинення статевої наруги?

Висновок експерта під час проведення судово-психіатричної експертизи є досить важливим доказом під час досудового розслідування, адже він визначає не тільки тяжкість наслідків вчиненого злочину для потерпілої особи, а й дає змогу встановити факт осудності, обмеженої осудності або неосудності підозрюваного.

Ще однією досить важливою експертизою, яку слід проводити під час досудового розслідування злочину минулих років, $\epsilon$ судовопсихологічна експертиза, яка полягає в аналізі нововиявлених фактів, що мають важливе значення для встановлення істини.

Щодо визначення судовопсихологічної експертизи серед науковців існують різні думки. Так,
Р.Я. Лемик розуміє їі як інститут юридичної психології, що, як правило, застосовується в цивільному, кримінальному i, рідше, адміністративному провадженні, тобто у провадженнях, підвідомчих суду [10, c. 10]. О. В. Ярош стверджує, що судово-психологічна експертиза дає змогу об'єктивно визначати міру покарання з урахуванням реальної мотивації, рівня усвідомленості підозрюваними особами своїх дій, індивідуально-психологічних якостей особистості підозрюваних і особливостей поведінки, що не може бути правильно оцінено без застосування психологічних методів [16, с. 18]. На думку В. М. Шерстюк, саме судовопсихологічна експертиза відіграє пріоритетну роль у впровадженні передових досягнень науки і техніки у практику боротьби зі злочинністю та сприяє надійності системи доказування [11, с. 4$]$.

Відповідно до кримінального процесуального законодавства слідчий зобов'язаний залучити експерта для проведення психіатричної експертизи в разі, якщо під час кримінального провадження буде встановлено обставини, які дають підстави вважати, що особа під час вчинення суспільно небезпечного діяння була в неосудному або обмежено осудному стані або вчинила кримінальне правопорушення в осудному стані, але після його вчинення захворіла на психічну хворобу, яка позбавляє ії можливості усвідомлювати свої дії або керувати ними (ч. 1 ст. 509 КПК України).

Також чинне законодавство визначає обов'язковість призначення комплексної психологопсихіатричної експертизи в разі необхідності вирішення питання про 
наявність у неповнолітнього підозрюваного психічного захворювання чи затримання психічного розвитку та його здатність повністю або частково усвідомлювати значення своїх дій і керувати ними в конкретній ситуації (ч. 1 ст. 486 КПК України). Так, ч. 2 ст. 486 КПК України визначає випадки призначення саме психологічної експертизи, зокрема, для з'ясування рівня розвитку неповнолітнього підозрюваного, соціальнопсихологічних рис особи неповнолітнього підозрюваного, які необхідно врахувати при призначенні покарання і обранні заходів виховного характеру.

Підстави для призначення судово-психологічної експертизи визначені у п. 2 ч. 1 ст. 509 КПК України:

- наявність, згідно з медичним документом, в особи розладу психічної діяльності або психічного захворювання;

- поведінка особи під час вчинення суспільно небезпечного діяння або після нього була або є неадекватною (затьмарення свідомості, порушення сприйняття, мислення, волі, емоцій, інтелекту чи пам'яті тощо).

Щодо судово-психологічної експертизи, то вона є досить актуальною при досудовому розслідуванні злочинів минулих років, адже вона характеризує не тільки психічно хвору особу, а й абсолютно психічно здорову, якій під впливом обставин можуть бути властиві певні психологічні процеси (затьмарення свідомоcті, порушення сприйняття чи пам'яті унаслідок стресу, психологічної травми, переляку, симуляції тощо).

Досить прогресивним, на нашу думку, є проведення психофізіологі- чної експертизи 3 використанням поліграфа. Науково обгрунтовано, що поліграф - це комп'ютерний апаратно-програмний комплекс, який дає змогу відслідковувати динаміку психофізіологічних реакцій досліджуваної особи при застосуванні поліграфологом тестових запитань (стимулів) та перетворення отриманих фізіологічних показників активності на електричні сигнали, що відображаються у вигляді графіків (поліграм) [12, с. 100]. Фізіологічними показниками, які реєструють поліграми, $є$ ритм дихання, рівень кров'яного тиску, інтенсивність потовиділення. Деякі детектори здатні ще й фіксувати напругу голосових зв'язок, розширення капілярів, реакцію зіниць очей тощо.

Так, наприклад, П. Д. Біленчук констатував, що в контексті науки психології доведено, що слід пам'яті людини як психологічний процес складається з трьох основних стадій: сприйняття, запам'ятовування та відтворення. Дві перші стадії формують у нервовій тканині головного мозку людини нервові зв'язки (утворення). Уявні образи минулого зберігаються в клітинах мозку у вигляді так званих асоціативних зв'язків. Запам'ятовування, як і сприйняття, має вибірковий характер, тому людина запам'ятовує не все, що сприймає, а саме те, що викликає в неї глибокі хвилювання або ж має для неї істотне значення [13, с. 157].

Тому, за умови наявності в пам'яті підекспертної особи ідеальних слідів відображення події минулого, яка розслідується, спеціальні стимули, що застосовує експертполіграфолог, виявлять інформаційні сліди відображення та допоможуть визначити їх походження. Стій- 
кі психофізіологічні реакції підекспертної особи зафіксує поліграф, а кількість повторів одного й того самого запитання - експертполіграфолог, що в різних тестових варіаціях зменшить імовірність ознак випадкового збігу даних, отриманих на комп'ютерних поліграмах $[14$, с. 48$]$.

Слід звернути увагу на твердження О. І. Мотляха, що проведення психофізіологічної експертизи з використанням поліграфа $\epsilon$ достатньо ефективним інструментарієм для отримання криміналістично значимої інформації в розслідуванні конкретного кримінального правопорушення, у тому числі нерозкритих злочинів минулих років. Науковець зазначає, що застосування цього науково-технічного приладу, зокрема в кримінальному судочинстві, створює додаткові засади для пізнання досудовим слідством того, що перебуває за межами звичайних людських можливостей і здібностей: знань, умінь, навичок, практики тощо, то ж ігнорування використання сучасних науково-технічних засобів у правоохоронній діяльності України, зокрема поліграфа в кримінальному судочинстві, обмежує належне й своєчасне розслідування зареєстрованого кримінального правопорушення, у тому числі нерозкритих злочинів минулих років [15, с. 206-209].
Отже, при досудовому розслідуванні злочинів минулих років важливим $\epsilon$ проведення судовомедичної і психофізіологічної експертизи. Разом із тим слід мати на увазі, що під час проведення цього виду експертиз виникають певні труднощі, адже досліджувані об'єкти 3 часом змінюються і втрачають деякі свої властивості та якості, але, не зважаючи не це, експерт як особа, яка має необхідні спеціальні знання, допомагає слідчому у встановленні важливих фактів і обставин під час розслідування злочинів минулих років.

Висновки. Отже, при досудовому розслідуванні злочинів минулих років важливим $€$ проведення судово-медичної та психофізіологічної експертиз. Їх можуть призначати у зв'язку з виявленням слідчим нових слідів та речових доказів вчиненого злочину або обмови в його вчиненні. Водночас слід мати на увазі, що під час проведення цього виду експертиз виникають певні труднощі, адже досліджувані об'єкти 3 часом змінюються і втрачають деякі свої властивості та якості, але, незважаючи не це, експерт як особа, яка має необхідні спеціальні знання, допомагає слідчому у встановленні дуже важливих фактів і обставин для розслідування даного кримінального провадження.

\section{Список використаних джерел}

1. Кримінальний кодекс України: Закон України від 5 квітня 2001 р. № 2341-III / Верховна Рада України. URL: http://zakon2.rada.gov.ua/laws/show/2341-14 (дата звернення: 25.02.2020).

2. Кримінальний процесуальний кодекс України: Закон України від 13 квітня 2012 року № 4651-VI. Верховна рада України. URL: http://zakon2.rada.gov.ua/laws/ show/4651-17/page (дата звернення: 25.02.2020). 
3. Про судову експертизу: Закон України від 01 січня 2019 р. № 2629-VIII / Верховна рада України. URL: https://zakon.rada.gov.ua/laws/show/4038-12 (дата звернення: 25.02.2020).

4. Меденцев А. А. Краткий курс лекций по судебной медицине. Волгоград: Издво Волги, 2004. 118 с.

5. Кузнецов В. В. Кримінальне право України: підручник. Київ : Атіка, 2006. 440 с.

6. Горбачевський В. Я. Топчій В. В. Окремі особливості досудового розслідування кримінальних проваджень про умисні вбивства. Науково-практичний журнал РНБО. 2013. № 1. С. 186-200.

7. Яковенко М. О. Особливості призначення судових експертиз при розслідуванні нерозкритих грабежів та розбоїв минулих років. Вісник Луганського державного університету внутрішніх справ імені Е. О. Дідоренка. 2012. С. 76-83. 397 c.

8. Гончаренко В. Г. Експертизи в судовій практиці. Київ : Атіка, 2005.

9. Калишник М. Я. Судебная психиатрия: учеб. для юрид. ин-тов и фак. Москва : Юрид. лит., 1966. 383 с.

10. Лемик Г. Я. Судово-психологічна експертиза в цивільному процесі України (проблеми теорії і практики): дис. ... канд. юрид. наук: 19.00.06. Київ, 2004. 238 с.

11. Шерстюк В. М. Організаційно-правові та морально-психологічні основи судово-експертної діяльності: дис. ... канд. юрид. наук: 12.00.09. Харків, 2007. 199 с.

12. Біленчук П. Д. Аудіовізуальна психофізіологічна діагностика людини: історія, теорія, практика: монографія. Київ : Атіка, 2013. 419 с.

13. Біленчук П. Д. Криміналістика: підручник. Київ : Право, 1997. 256 с.

14. Дідик В. Я. Огляд практики використання поліграфа «детектра брехні» Київ : Право, 1999. 103 с.

15. Мотлях А. І. Ефективність використання поліграфа в розслідуванні нерозкритих злочинів минулих років. Порівняльно-аналітичне право. Київ : Атіка, 2015. С. 206-209.

16. Ярош О. В. Судово-психологічна експертиза неповнолітніх, обвинувачуваних за агресивні злочини: автореф. дис. ... канд. психол. наук: 19.00.06. Харків, 2008. 20 с.

\section{References}

Medentsev, A. A. (2004). Short course of lectures on forensic medicine. Volgograd: Volga Publishing House [in Russian].

Kuznetsov, V. V. (2006). Criminal Law of Ukraine: a textbook. Kyiv: Attica [in Ukrainian].

Gorbachevsky, V. Y., Topchiy V. V. (2013). Some peculiarities of pre-trial investigation of criminal proceedings about premeditated murder. NSDC Scientific and Practical Journal. Kiev [in Ukrainian].

Yakovenko, M.O. (2012). Features of the appointment of forensic expertise in the investigation of undisclosed robberies and robberies of past years. Bulletin of Lugansk State University of Internal Affairs named after E. O. Didorenko. Lugansk, 76-83 [in Ukrainian].

Goncharenko, V.G. (2012). Expertise in court practice. Kyiv: Attica [in Ukrainian].

Kalishnik, M.Y. (1966). Forensic Psychiatry: Study. for jurid. inst and fac. Moscow: Law. Lit. [in Russian].

Bilenchuk, P.D. (2013). Audiovisual psychophysiological diagnostics of a person: history, theory, practice. Kyiv: Attica [in Ukrainian].

Bilenchuk, P. D. (1997). Forensics: a textbook. Kyiv: Law [in Ukrainian].

Didyk, V. Y. (1999). Review of the practice of using the polygraph "lie detector". Kiev: Law [in Ukrainian]. 
Motlyakh, A. I. (2015). The effectiveness of the use of the polygraph in the investigation of unsolved crimes of the past years. Comparative analytical law. Kyiv: Attica, 206-209 [in Ukrainian].

N. Simonenko, Candidate of Legal Sciences, Associate Professor of Criminal Law Department of National Academy of Internal Affairs e-mail: Natalk_88@ukr.net; ORCID:0000-0003-1048-278X

\section{Peculiarities of conducting individual court examinations during the investigation of crimes of the past years}

This article is concerning on investigation of forensic and psychophysiological examination during the pre-trial investigation of crimes of the past years. The author pays special attention to issues related to forensic, forensic psychiatric and forensic psychological examination as well as to conducting psychophysiological examination using a polygraph.

Quite often in practice of pre-trial investigation and subsequent court proceedings of crimes of the past years it is necessary to deal with issues that cannot be solved by one specialist because they do not have relevant special knowledge. In this case, there is a need for forensics. Equally important is to establish new evidence and to verify the evidence collected during the pre-trial investigation of crimes of past years. The expertise conclusion is one of the most important pieces of evidence in pre-trial investigation of crimes. The grounds for conducting and procedure of appointment the expert examination in criminal proceedings are stipulated by the CPC of Ukraine, the Law of Ukraine "On Judicial Expertise" and the Instruction on the Appointment and Conduct of Judicial Expertise and Expert Research, approved by the order of the Ministry of Justice of Ukraine.

Therefore, in pre-trial investigation of crimes of the past years it is important to conduct forensic and psychophysiological examination. They may be appointed in with regard to the detection of new traces and physical evidence of a crime by an investigator or due to a slander in committing it. However, it should be borne in mind that during this type of examination there are certain difficulties, because the objects under study may be changed over time and lose some of their properties and qualities. Despite this, an expert as a person who has special knowledge assists an investigator in establishing important facts and circumstances for the investigation of respective criminal proceedings.

Keywords: expert; crimes of the past years; investigation; forensic examination; forensic psychological examination; psychophysiological examination using polygraph.

(C) Симоненко Н. О., 2020 